\title{
Audits, Audit Quality and Signaling Mechanisms: Concentrated Ownership Structures
}

\author{
Marianne Ojo ${ }^{1}$ \\ North-West University, South Africa
}

\begin{abstract}
Do jurisdictions with concentrated ownership structures require less reliance on audits as corporate governance mechanisms and devices? Why do concentrated ownership structures still prevail in certain jurisdictions which are considered to be "market based corporate governance systems"? More importantly, if failures and causes of recent financial crises are principally attributable to the fact that market based corporate governance mechanisms, such as financial regulators, are not optimally performing their functions, why is the role of audits still paramount in such jurisdictions? These are amongst some of the questions which this paper attempts to address.

The ever increasing growth of institutional investors in jurisdictions - particularly those jurisdictions with predominantly concentrated ownership structures, with their increased stakes in corporate equity, also raises the issue of accountability and the question as regards whether increased accountability is fostered where institutional investors assume a greater role - as opposed to position which exists where increased stake of family holdings (family controlled structures) arises.
\end{abstract}

JEL: K2, M41, M42,

Keywords: Audit Quality, Corporate Governance, Concentrated Ownership Structures, Capital Market Economies, Institutional Investors.

\section{INTRODUCTION}

\subsection{Audits as Vital Signaling Devices in Capital Markets}

The audit serves (and should serve) as a vital capital market signaling mechanism that conveys quality information to the markets, investors and other users of financial information, that information provided by the financial statements, financial reports of an enterprise, through its management, is relatively reliable. From this perspective, it may be asked whether accurately conveying information about the financial situation or position of a firm to investors, prevents or mitigates the likelihood of the occurrence of systemic risks. Further, would the mitigation of information asymmetries within capital markets and the financial industry as a whole, reduce the possibility of systemic risks occurring?

It could be argued that conveying accurate and credible information about the financial situation of a firm or enterprise to its investors, could actually trigger bank runs - if the audit generates a negative signal - that is, if the auditor issues a qualified opinion about the financial statements. The manner whereby the opinion is conveyed to the investors then becomes crucial in preventing bank runs. Even timely information could trigger bank runs - the "when" then probably becomes as important as "how" the information is handled. Whilst the level of inaccuracy or accuracy of the information conveyed by audits certainly has its repercussions, their role in addressing information asymmetries is quite evident. If audits are as reliable as they should be, whether or not they generate negative or positive signals, the timeliness, completeness and accuracy levels of such information - as well as the manner with which such information is handled, will be crucial to the triggering or avoidance of systemic risks. In this sense, a clear link between the quality of information, informational asymmetries and systemic risks can be established.

\section{LITERATURE REVIEW}

\subsection{Audit Quality and Concentrated Ownership Structures}

In matters relating to information asymmetries, it may appear that audits and audit quality, play a more vital role in capital market based dispersed ownership systems than concentrated ownership structures. According to Goshen and

\footnotetext{
${ }^{1}$ Corresponding Author: marianneojo@hotmail.com
} 


\section{American Research Journal of Humanities and Social Sciences, Volume 1, Issue 2, April 2015 ISSN 2378-7031}

Hamdani (2013:6), ,control matters for entrepreneurs because it allows them to overcome asymmetric information vis-à-vis investors and pursue their business idea in whatever manner they see fit, thereby securing their ability to capture the idiosyncratic value that they attach to their execution of their business idea.

However, as commented by Clarke and dela Rama (2008:7). ......, ,the belief in the disappearance of the control by proprietary interests of the largest corporations, is to be questioned, not only given the patterns of ownership holdings within and between corporations“, but also because of „the extent of interlocking directorships, connections with banks and other financial institutions, as well as their real owners, and wider networks or ownership and influence."

This is further illustrated by the situation with the United States, the ,archetype of the market based corporate governance system", whereby it is revealed that i) $59 \%$ of listed US corporations have a controlling shareholder - a situation considered higher than that which exists in Japan; ii)that 36\% of US corporations family-controlled (a situation which is similar to the position which exists in Germany, but higher than the situation which exists in the UK, France or Japan); and iii) that $24 \%$ of US corporations are controlled and managed by a family - a similar situation to that which exists in East Asia (Clarke and dela Rama, 2008:7,8; Gadhoum et al: 2008, cited).

As well as the increased role assumed by institutional investors (as opposed to individual investors), the controversial nature and difficulty of distinguishing between ownership and control is further illustrated by Clarke and dela Rama (2008:9), who highlight the fact that even though ownership and management may comprise of different people, they may not be separate.

The ever increasing role of institutional investors in jurisdictions with concentrated ownership structures, with their increased stakes in corporate equity, also raises the issue of accountability and the question as regards whether increased accountability is fostered where institutional investors assume a greater role - as opposed to increased stake of family holdings.

Goshen and Hamdani (2013: 4) argue that unlike diversified minority shareholders, a controlling shareholder „typically shoulders the costs of being largely undiversified and illiquid.“

In trying to reason why the controlling shareholder chooses to retain control, they respond to this by adding that agency costs, ,the availability of private benefits of control“, provided a key solution to this reasoning, since in their opinion, the controlling shareholder could implement the dominant position to "consume private benefits" such as self-dealing transactions, the employment of family members, at the expense of minority shareholders."

The success, survival and resilience of many family controlled enterprises is evidenced in the U.S - as well as several parts of continental Europe. A factor which could be attributed to this is that such structures compel a higher degree of accountability than that which is typically manifested by dispersed ownership structures in marked based corporate governance structures or those concentrated ownership structures which are largely governed by institutional investors. Such level of accountability and commitment to the firm also constitutes a plausible explanation for the requirement and proposals that management of several enterprises retain blocks of shares for a reasonable period of time - a demonstration of their loyalty, as well as their commitment to the interests of the firm.

The "unlocking" and discernment of owners in complex ownership structures will certainly provide a means to greater fulfillment of the goals of Board independence - a key feature in jurisdictions such as the UK where the distinction between the Board of directors, non-executive directors and chairmen of the company, has become paramount - particularly since the introduction of the Cadbury Report in 1992. The Cadbury Report has certainly paved the way for greater reforms which have resulted in a more refined Combined Code of Corporate Governance - as evidenced by the Higgs Report. As well as directing attention to the importance of the definition of the role of the Board, the Higgs Report also accords great focus to the distinction between the roles of the chairman, chief executive and non-independent executive directors.

\section{Methodology}

In arriving at a conclusion, the following approach has been adopted, namely a balancing of goals and objectives of dispersed ownership structures against those of concentrated ownership structures. Furthermore, findings from the report prepared by Oxera for the European Commission,were also taken into consideration. 


\subsection{Which Risks are Worth Bearing? Balancing Goals and Objectives of Dispersed Ownership Structures and Concentrated Ownership Structures}

Goshen and Hamdani (2013:30) state that: with concentrated ownership structures, investors face the risk that although the entrepreneur will efficiently manage the firm and realize the idiosyncratic value, there also exists the risk that commitment to share residual cash-flows pro-rata will be avoided and that private benefits of control will be eliminated. Should job security (a feature and goal which many concentated ownership structures defend) preside over the goal of profit maximization (or the need to secure the highest dividend payouts)? Clearly there should be a balance between these objectives - another possible explanation for the support towards the move to commitments aimed at embracing wider stakeholders and corporate social responsibility. The need to balance goals and objectives, however, should also be complemented by weighing the devastating impact of firms' collapses and the consequences of such collapses on wider stakeholders.

Even though it has been argued by several commentators that sanctioning role played by regulatory bodies and financial markets in sanctioning management, constitute flaws which have contributed to the recent Financial Crisis, the role played by audits and auditors, however, have definitely also played a crucial role in contributing to many of the recent financial and corporate collapses.

Even though joint audits (that is, mid-tier firms carrying out joint audits with Big Four firms, as a means of increasing their presence at international level,), has been proposed and regarded as "the priority step in tackling the concentration issue" (European Commission, 2011 at page 6 of 11), whether such audits can also facilitate greater levels of audit independence also constitutes an interesting matter.

\subsection{Ownership Rules of Audit Firms and Audit Market Concentration}

The focus on ownership rules of audit firms, derives not only from consequences emanating for audit market concentration, but also from the impact generated on auditor independence. Employee ownership, as well as "the resulting profit sharing amongst senior auditors" serves as good signaling mechanism of the quality of audit services to the market (European Commission, 2007: page 88). The importance of retaining audit quality is also a concern in the bid to provide greater access, expansion and entry to the audit market. Would the admission of more players from the mid-tier audit firms into the audit market generate more positive impacts and consequences for audit independence? It is certainly the case that increased audit concentration within the audit market certainly has consequences for audit independence since there is less choice and competition between the firms in the market, as well as devastating consequences, in respect of systemic risk, if the demise of another Big Four audit firm, should occur.

According to a report prepared by Oxera for the European Commission (2007), it was highlighted that "the key question to be answered, is to what extent the corporate structures adopted by audit firms, whether driven by rules or by commercial factors, affect the market's ability to deliver a more open configuration that would reduce some of the concerns expressed about concentration and choice in the audit market."

Main findings of the Report, as illustrated under the subheadings below, are as follows:

\section{Current ownership rules and opportunities created by their potential relaxation}

That a relaxation of current ownership and/or management rules might not result in immediate change in ownership structures of audit firms, but that it would, however, create a real possibility and provide incentives - such that alternative structures might emerge over time.

\section{Impact on access to capital}

That there exists evidence from current literature that several aspects of the employee-owned corporate form of ownership adopted by audit firms are likely to increase required rates of return of audit firms, as well as restrict their ability to access capital initially.

\section{Impact on entry and expansion into the market for large audits}

That restrictions on access to capital represents one of several potential barriers to entry into the market for large audits and particularly, capital was found to be critical only for those firms seeking to expand into the market for larger audits. 


\section{American Research Journal of Humanities and Social Sciences, Volume 1, Issue 2, April 2015}

ISSN 2378-7031

\section{$>$ Impact on auditor independence}

That main rationale for ownership and management restrictions is related to their impact on the independence of auditors from potentially negative outside influences.

\section{RESULTS}

From the above findings, the link between audits, audit quality and audit independence can be illustrated. Audit quality certainly has immense and considerable consequences - particularly in matters relating to audit concentration and moral hazard. The significance of the exit of another "Big Four" audit cannot be over emphasized. Hence greater appreciation should be accorded to the contribution made by mid-tier audit firms, as well as their potential in facilitating more objectivity and greater independence - particularly where they are involved in collaborations such as joint audits.

\section{CONCluSion}

\subsection{Sending the Right Signals to the Market}

Sending the right signal to the markets - that no firm, and certainly, no Big Four audit firm, is "too big to fail" is of immense importance in addressing the issue of moral hazard. In this sense, greater acknowledgement is to be given to mid-tier audit firms through an appreciation of their ability to contribute to audit quality. Whilst adequate and appropriate punitive sanctions should be directed at the management of a firm, audit firms and their roles in corporate collapses, constitute ever increasing focal points - particularly given the recent trend demonstrated by concentrated ownership structures - a move towards capital market based governance structures.

Even though family owned structures are to be commended in fostering greater accountability and commitment, an increased trend towards the growth of institutional investors and the need for increased monitoring - both internally and external to the corporate structures, warrants an effective corporate governance device which would not only enhance greater transparency, but also facilitate greater disclosure within corporate structures (and particularly, complex corporate structures).

The lack of adequate mandatory audit firm rotation is also a feature and element which has affected audit quality over the past years. Whilst it is certainly beneficial to retain the services of an audit firm for a certain period of time - given benefits which accrue from having acquired in-depth knowledge about the client firm, disadvantages could arise owing to impaired judgment and the ability to objectively approach a matter as independently as is expected of such an audit firm. Familiarity or an undue degree of familiarity with the records of a client firm, could also facilitate cover-ups and creative accounting practices which have been so evident from recent and previous financial crises.

Up till 2013, there had been no requirement at European level for the mandatory rotation of audit firms - even though some member states had gone further than Article 42 of Directive 2006/43/EC in requiring mandatory audit firm rotation. This however, has changed with mandatory requirement - pursuant to a draft law that would "require public-interest entities such as banks, insurance firms, and listed companies to rotate audit firms every 14 years"(and such period could be extended to 25 years when certain safeguards are put into place). Other notable features of the Draft Law also include (Tysiac, 2013):

$>$ Prohibition of "Big Four-only" contractual clauses that require a company's audit to be done by one of the Big Four accounting firms (Deloitte, Ernst \& Young, KPMG, and PwC).

$>$ Requirement that auditors of public-interest entities (PIEs) publish audit reports according to international standards and provide shareholders and investors with a detailed understanding of what the auditor did and an overall assurance of the accuracy of the company's accounts.

$>$ Prohibition of audit firms from providing non-audit services that could jeopardize independence.

Proposals, legislation and efforts aimed at encouraging partnerships between Big Four audit firms and mid-tier firms are also welcomed, as well as external investments in mid-tier audit firms - provided that audit quality is retained. Reducing the audit expectations gap is another aspect which needs to be accorded greater focus as this would contribute immensely towards addressing informational asymmetries between users of information conveyed about the financial statements and reports (and principally stakeholders of firms) and the management of a firm. Whilst conveying the most accurate information is certainly not guaranteed to ensure that bank runs will not occur, the manner in which such information is handled could prove crucial in averting devastating consequences of systemic 


\section{American Research Journal of Humanities and Social Sciences, Volume 1, Issue 2, April 2015 ISSN 2378-7031}

risks. In this sense, the auditor bears the responsibility of ensuring that audits are properly carried out whilst management needs to ensure that such information conveyed by audits is dispersed in a manner which not only serves the best interests of shareholders, but that of the market as a whole.

\section{REFERENCES}

[1] Clarke, T. and dela Rama M., (2008) Fundamentals of Corporate Governance, Sage Publications London, Thousand Oaks CA ISBN 978-1-4129-3589-0

[2] European Commission, (2007) Ownership Rules of Audit Firms and their Consequences For Audit Market Concentration October 2007 http://ec.europa.eu/internal_market/auditing/docs/market/oxera_report_en.pdf

[3] European Commission, (2010) GREEN PAPER Audit Policy: Lessons from the Crisis http://eurlex.europa.eu/LexUriServ/LexUriServ.do?uri=COM:2010:0561:FIN:EN:PDF

[4] European Commission, (2011) Study on the effects of the implementation of the "acquis" on statutory audits of annual and consolidated accounts including the consequences on the auditmarket http://ec.europa.eu/internal_market/auditing/ reform/

[5] European Commission, (2011) Proposal for a DIRECTIVE OF THE EUROPEAN PARLIAMENT AND OF THE COUNCIL amending Directive 2006/43/EC on statutory audits of annual accounts and consolidated accounts http://ec.europa.eu/ internalmarket/auditing/docs/reform/directive_en.pdf

[6] Goshen, Z. and Hamdani, A., (2013) Concentated Ownership Revisted: The Idiosyncratic Value of Corporate Control

[7] Ojo, M. (2006). General Literature on the Audit Expectations Gap, Journal of Forensic Accounting, Vol. VIII, Nos. 1 \& 2, January-December 2007

[8] Ojo, M (2009), Regulating the International Audit Market and the Removal of Barriers to Entry: The Provision of Non Audit Services by Audit Firms and the 2006 Statutory Audit Directive (November 2009) Published in European Public Law Journal (December 2009) and Regulation of Financial Institutions Journal CMBO (December 2009)

[9] Tysiac, K. (2013) „Europe Takes Step Toward Mandatory Audit Firm Rotation“, Journal of Accountancy April 2013 http://w ww.journalofaccountancy.com/news/20137862.htm

\section{AUTHOR's BIOGRAPHY}

Marianne Ojo is a Professor at the Faculty of Commerce and Administration, Department of Economic and Decision Studies at North-West University. She is also affiliated with the Legal Scholarship Network.

Her research papers can be accessed via the following links:

The Social Science Research Network (SSRN) at:

http://papers.ssrn.com/sol3/cf_dev/AbsByAuth.cfm?per_id=1257850

as well as:

http://econpapers.repec.org/RAS/poj3.htm

http://ideas.repec.org/e/poj3.htm

Email contsct: marianneojo@hotmail.com 